\title{
THE WRITS OF ERROR CORAM NOBIS AND CORAM VOBIS
}

\author{
EDWARD N. ROBINSON*
}

After the completion of an unsuccessful litigation, an attorney may find that certain facts existed which, if they had been brought to the attention of the court during the trial, would have prevented the judgment. Yet, the more familiar procedural remedies may be inappropriate or may have long before expired leaving him without apparent recourse to the courts. With origins buried deep in the annals of procedural history, there is a common law writ known as the writ of error coram nobis or coram vobis, which has aided many a client and lawyer in the hour of desperation. It is the purpose of this article to reacquaint the lawyer with certain aspects and characteristics of the writ and to consider its availability in those jurisdictions where it has not been abolished. ${ }^{1}$

\section{General Usage of the Writ}

Coram nobis (before us, the King, i.e. the King's or Queen's Bench) is so called from that clause in the old forms which described the record and process as remaining "before us" (quae corum nobis resident). Coram vobis (before you, the justices) was the corresponding term used in Common Pleas. In the United States, coram nobis is the name generally employed, although some courts use coram vobis to refer to a writ directed by a court of review to the

\footnotetext{
* 3rd year law student, Duke University; B.S. U.S. Military Academy, 1945.

1 As to the origin and development of the writ see Sanders v. State, 85 Ind. 318, 325 (1882); Orfield, The Writ of Error coram Nobis in Civit Practice, 20 VA.L.Rev. 423, 425 (1934); Note, 10 Neb.L.BuLL. 314 (1932); Comment, 34 Conivel L.Q. 596 (1949); Tweed v. Lockton, 35 Del. 474, 167 A. 703,705 (1932). The writ of error coram nobis was abolished in England by the Common Law Procedure Act. Orfield, Crrmiral PnoCEDURE from ARrest to ApPEAL, 522 (1947).
} 
court which tried the cause. ${ }^{2}$ From early times, the writ has been used in both criminal and civil proceedings. ${ }^{3}$

The distinction between an ordinary writ of error or appeal and a writ of error coram nobis is that the former is brought for an error of law apparent on the record and takes the case to a higher tribunal, while the latter is brought for an error of fact not appearing and lies in the court which tried the case. A writ of error coram nobis is not an appellate remedy. The purpose of this writ is not to authorize a court to review its opinion, but only to vacate some adjudication made, ${ }^{5}$ and should the error alleged be in the judgment itself, then remedial action must be sought through appeal or writ of error. ${ }^{6}$

The facts, upon which the writ of error coram nobis is sought, must have existed at the time of the pronouncement of the judgment. ${ }^{7}$ The writ will not lie to contradict or put in issue any fact that has already been adjudicated, even though exroneously decided. ${ }^{8}$ The reason the fact was not disclosed at the prior trial must have been due to fraud, duress, or excusable error, and not negligence on the part of the party now seeking the writ. ${ }^{9}$ Moreover, the fact in question must be such as would have prevented rendition of the judgment at the former trial, had it been available,

2 Tweed v. Lockton, 35 Del. 474, 167 A. 703, 705 (1932); Ballentine's Law Dictionary, Coram Vobis, p1373. "Coram nobis is issued by the court in which the judgment assailed was rendered; while the writ of coram vopis is issued by a supervening court to a lower court in which the judgment was rendered." Roughton v. Brown, 53 N.C. 393 (1861). See also Teller v. Wetherell, 6 Mich. 45 (1858).

${ }^{3}$ Note, 59 YALE L.J. 786 (1950); Orfield, The Writ of Error Coram Nobis in Civil Practice, 20 VA. L. REv. 423 (1934).

Roughton v. Brown, 53 N.C. 393 (1861); People v. Lyle, 21 Cal. App. 2d 132, 68 P.2d 378 (1937); Tweed v. Lockton, 35 Del. 474, 167 A. 703 ; Fine v. United States, 67 F.2d 591, 592 (7th Cir. 1933); 10 A.L.R. 648 (1921); 30 A.L.R. 686 (1924).

E Madden v. Ferguson, 182 Ill.App. 210 (1913).

- Williams v. Edwards, 12 N.C. 118 (1851).

- Collins v. State, 66 Kan. 201, 71 P. 251 (1903); People v. Walton, 10 Cal.App.2d 413, 51 P2d 1117 (1935).

${ }^{8}$ People v. Lyle, 21 Cal. App.2d 132, 68 P.2d 378 (1937); People v. Budasi, 287 Ill.App. 117, 4 N.E.2d 756 (1936).

- Sanders v. State, 85 Ind. 318 (1882); Note, 58 A.L.R. 1286; Wheeler v. State, 158 Ind. 687,63 N.E. 975 (1902). 
not that such facts might have produced a different result had they been known to the judge and jury. ${ }^{10}$ Though there is some authority contrary, it seems fairly well settled that evidence cumulative to that provided at the trial is insufficient to justify issuance of the writ ${ }^{11}$ as is newly discovered evidence going to the merits of the issues decided.12

The writ of error coram nobis is strictly a common law writ and does not issue out of a court of chancery. ${ }^{13}$ It does not lie in a court where there is no record of the case, ${ }^{14}$ and only a party to the judgment or one in privity to him can prosecute the writ. ${ }^{15}$ There is a division of authority as to whether it is a writ of right ${ }^{16}$ or is to be issued in the discretion of the court.17 However, most courts, which today recognize the writ, require a sworn affidavit showing to a reasonable certainty error of fact resulting in the erroneous decision. ${ }^{18}$ Any presumptions indulged in by the court entertaining the petition for writ of error coram nobis are to be in favor of the original judgment.19

The writ may be issued after the trial term has expired, ${ }^{20}$ but whenever possible the judge who heard the original case should pass on the issuance of the writ granting a new

${ }^{10}$ Corr v. Buddendorff, 98 Miss. 98,54 So. 84 (1911); Thompson v. State, 154 Fla. 769,18 So.2d 788 (1944).

11 Howard v. State, 58 Ark. 229, 24 S.W. 8 (1893); Dobbs v. State, 63 Kan. 321, 65 P. 658 (1901). In the latter case, the court denied a new trial where it was sought on the grounds that it could be proved that another committed the crime for which the defendant was convicted.

13 Note, 33 A.L.R. 84 (1924); State V. Asbell, 62 Kan. 209, 61 P. 690 (1900); MIandell v. People, 76 Colo. 296, 231 P. 199 (1924); U.S. v. Gardzielewski, $135 \mathrm{~F} .2 \mathrm{~d} 271$ (7th Cir. 1943). There is some anthority contra. See George v. State, 211 Ind. 429, 6 N.E.2d 336 (1937).

13 Reid v. Strider, 7 Gratt. 76 (Va. 1850)-(or $48 \mathrm{Va}$ ) 39).

14 Roughton v. Brown 53 N.C. 393 (1861); U.S. v. Plummer, 27 Fed. Cas. 561 , No. 16,056 (C.C. D. Mass. 1859); Bradford v. White, 130 Ark, 532, 197 S.W. 1175 (1917).

${ }^{23}$ Calloway v. Nifong, 1 Mo. 223 (1822); State ex rel. Potter v. Riley, 219 Mo. 667, 118 S.W. 647 (1909).

${ }^{16}$ Sanders v. State, 85 Ind. 318 (1882).

17 Smith v. Kingsley, 19 Wend. 620 (N.Y. 1838); Tyler v. Morris, 20 N.C. 625 (1839); Johnson v. State, 144 Fla. 87, 197 So. 721 (1940).

18 Alexander v. State, 20 Wyo. 241, 123 P. 68 (1912).

${ }^{3}$ Chapman v. North American Life Ins. Co., 292 IIl. 179, 126 N.E. 732 (1920).

so Nickels v. State, 86 Fla. 208, 98 So. 502 (1923). 
trial.21. Where a conviction has once been affirmed by an appellate court, it is generally held that the trial court cannot entertain the application for the writ of coram nobis, without the permission of the appellate court.22 The legal sufficiency of the evidence to justify setting aside a judgment, on writ of coram nobis, is a question of law on which the trial court's finding is not binding on the appellate court, which, in effect means that where no appeal has been had from the original hearing, the petition should be filed in that trial court and in case of an adverse ruling, an appeal may be had to an appellate court for a review of the legal sufficiency of the grounds upon which the petition is based.23

It is generally said that no statute of limitations will run against issuance of the writ, while others bar it because of laches. ${ }^{24}$ Even though a defendant has paid his fine and served his sentence, the question as to issuance of the writ

21 Murphy v. Daly, 296 Ind. 179, 188 N.E. 769 (1934). Judge is without jurisdiction during vacation to hear or determine matters submitted by writ of coram nobis. Special judge who rendered final judgment retained jurisdiction to entertain petition for writ of error coram nobis filed six years after judgment, and another special judge appointed to hear petition had no jurisdiction where it was not shown that the first judge refused to act or was disqualified. State ex. rel. Chadd v. American Surety Co. of N.Y., 66 S.W.2d 941 (Mo.App. 1933).

22 Washington v. State, 92 Fla. 740, 110 So. 259 (1926); Latham v. Hodges, 35 N.C. 267 (1852). Contra: Buckler v. State, 173 Miss. 350, 161 So. 683 (1935).

23 State v. Hudspeth, 191 Ark. 963, 88 S.W.2d 858 (1935); Partlow v. Indiana, 194 Ind. 172, 141 N.E. 513, 30 A.L.R. 1414 (1923). The reason for the rule is that a lower court has no control or right of review over the ruling of a higher court. However, the cases cited say nothing about getting authority of an upper court to petition to petition the triai court for review which would obviously satisfy the rationale of these cases. State v. Calhoun, 60 Kan. 623, 32 P. 38 (1893); Ernst v. State, 111 Kan. 350, 207 P. 192 (1922).

2 State v. Wallace, 209 Mo. 358, 108 S.W. 542 (1908); Ernst v. State, 179 Wisc. 646, 192 N.W. 65 (1923). Application $41 / 2$ years after conviction is barred by laches. People v. Vernon, 9 Cal.App.2d 138, 49 P.2d 326 (1935). One seeking writ due to insanity at time of trial must bring the petition in less than 2 years after regaining sanity. Newcomb $v$. State, 129 Neb. 69, 261 N.W. 348 (1935). Rules of Civil Procedure, Art. 39, Sec. 8, devised by the American Judicature Society would allow 3 years after the entry of judgment in civil cases. Bulietin XIV, American Judicature Society (1919) 174. The federal courts have heid 6, 9, and 18 years as sufficient to bar the application. For argument against the writ being barred by laches, note, 59 YALE L.J. 792, N. 28 (1949). 
is not moot, for the defendant has a right to clear his name. ${ }^{25}$

Often, statements of general propositions of law lose their significance, unless they are joined with examples of actual application of these propositions to specific cases. For that reason, consider the following rulings where unsuccessful litigants have subsequently applied for writs of error coram nobis. The writ has been allowed where the defendant has pleaded guilty through mistake, duress, or fraud ${ }^{26}$ where a person was convicted while totally insane ;i $^{\mathbf{2}}$ where a person under eighteen was sentenced to the penitentiary in violation of a state statute $;^{28}$ where the clerk of the court failed to obey a rule requiring him to change the assignment upon the wrapper of the case, as the result of which a judgment by default was entered by a judge whose name was on the files; ${ }^{29}$ where a judgment was rendered against a minor $; 30$ where a person attempted embracery with one of the jurors $; 31$ to exclude perjured testimony as to the identity of the defendant ; ${ }^{32}$ where the court was misled by fraud or mistake to suppose that it had jurisdiction over the defendant's person and the fact is not apparent on the record; ${ }^{33}$ to allow a corporation which assumed liabilities of a dissolved corporation to set aside a judgment rendered against the dissolved corporation without notice to its successor

25 Stephenson v. State, 205 Ind. 141, 186 N.E. 293 (1933).

2s State v. Calhoun, 50 Kan. 532, 32 Pac. 38 (1893); Sanders v. State, 85 Ind. 318, 44 Am.Rep. 29 (1882) ; State v. Ray, 111 Kan. 350, 207 P. 192 (1922); Dubosky v. State, 183 Ind. 488, 109 N.E. 742 (1915); Ernst v. State, 179 Wis. 646,192 N.W. $65, a f f^{\prime} d, 181$ Wis. 155,193 N.W. 978 (1923).

27 Adler v. State, 35 Ark. 517, 37 Am.Rep. 48 (1880); Linton v. State, 77 Ark. 532, 81 S.W. 608 (1904). Where sanity was suggested formally or informally at or before the trial, the writ will not lie after conviction to raise the question. Sease v. State, 157 Ark. 217, 247 S.W. 1036 (1923).

2s Ex parte Gray, 77 Mo. 160 (1882).

? Hallbrook v. Lawton, 207 Ill. App. 497 (1917).

$\approx$ Iraricofe v. Schwaner, 196 Mo.App. 595, 196 S.W. 46 (1917).

${ }^{31}$ Cutlett v. Chestnut, 117 Fla. 538, 158 So. 418 (1935). Case denied the writ but on the grounds that the alleged embracery was committed by one not a party to the suit and it was not shown that it resulted in influencing the juror.

32 Davis v. State, 200 Ind. 88,161 N.E. 375 (1928). It was there pointed out that the court has a discretion to grant the writ in case of perjured testimony of a material witness upon which the verdict probably depended. Accord, Shock v. Indiana, 230 Ind. 469,164 N.E. 625 (1929).

${ }_{33}$ Sowers-Taylor Co. v. Collins, 14 S.W.2d 692 (Mo.App, 1929). 
where the court was not informed of the succession; ${ }^{34}$ where the court assumed non-existent facts, absence of which entirely defeats jurisdiction; ${ }^{35}$ where defendant was sued on bank stock and was misled by being told that all other stockholders were being sued along with her and that the case was only a test case; $;^{36}$ to raise a due process question of conviction. ${ }^{37}$

This short recital of cases in which the writ of error coram nobis was granted is far from complete due to the fact that it only considers borderline cases in which the writ was denied by the trial court and the appellate courts of the particular state reviewed the ruling. Hence the many cases in which coram nobis was allowed by the trial courts are not here reflected. As a result of this type of coverage, the following cases in which denial of the writ was affirmed is necessary for a more thorough understanding of the true characteristics and limitations of the writ. Coram nobis has been denied by appellate courts where they were sought on the grounds that a prosecuting witness was insane ${ }^{38}$ to redress an irregularity such as misconduct of jurors, since such matters may be remedied by motion for a new trial $;^{39}$ that defendant can show that another person committed the wrong $;^{40}$ that a material witness falsely testi-

\footnotetext{
36 Hecht Bros. v. Walker, 224 Mo. App. 1156, 35 S.W.2d“372 (1931).

$\therefore$ However, determination of the fact necessary to jurisdiction, even though erroneous, defeats new trial on that issne by writ of coram nobis. Baker v. Smitb, 226 Mo.App. 510, 18 S.W.2d 372 (1931).

$\approx$ Rose v. Murrow, 10 Tenn.App. 698 (1929).

$\approx$ Conizio v. State of N.Y., 327 U.S. 82, (1946).

3 Boyd v. Smyth, 200 Iowa 687, 205 N.W. 522 (1925).

$\approx$ Hamlin v. State, 67 Kan. 724, 74 P. 242, 36 A.L.R. 1443 (1903). The writ will not lie to redress irregularities occurring during the triai, such as misconduct of the jury, court, or any officer, except under circum. stances amounting to extrinsic fraud. Information irregularly obtained by jurors from judge as to how long defendant, if given life imprison. ment, would probably be detained is remedial not by coram nobis but by motion for new trial. People v. Reid, 195 Cal. 249, 232 P. 457, 36 A.L.R. 1435 (1924).

so Howard v. State, 58 Ark. 229,24 S.W. 8 (1893). Such allegation calls for a review of the issue of fact raised by defendant's plea of not guilty, and the writ does not lie to contradict an issue and finding of fact. Affidavits filed by persons admitting commission of larceny for which defendant had been convicted only constituted newly discovered evidence and will not justify writ of coram nobls. This would be an
} 
fied ; $^{41}$ that the defendant was unable to appeal in time ;2 that $^{42}$ jurors made false statements, not discovered until later ${ }^{43}$ that a juror had expressed an opinion in the case prior to trial $;^{44}$ that defendant, judge, and attorney were ignorant of statutes providing that evidence in a civil trial may not be used in criminal trials and such evidence was used in the conviction of the defendant; 45 that defendant was prevented from obtaining a witness through fear of violence; ${ }^{46}$ that defendant can now show a legal divorce from his first wife and a void second marriage due to duress where he was previously convicted of bigamy; ${ }^{47}$ that the presiding judge was not authorized to preside ; ; $^{48}$ that counsel for defendant refused to file a motion for a new trial where the defendant confessed in open court; 40 that prosecutrix now swears she perjured herself at the trial in which the defendant was convicted $;^{49}$ (a) and that defendant made false statements to shield a party who promised to pay his fines. ${ }^{50}$

In attempting to reconcile the above enumerated holdings, two rather well established principles are to be kept in mind: (1) the writ of error coram nobis lies only where no other remedy is available, which in itself would lead to a discrepancy in rulings as to grounds for granting the writ, due to the variations in statutory and common law proced-

\footnotetext{
easy way to obtain a new trial in every case and then the newly admitted wrongdoers could refuse to testify in open court against themselves. It would throw the doors open to fraud and perjury. If newly discovered evidence showed that petitioner was wrongly convicted, it furnishes a basis for application to the pardoning power but does not warrant a new trial under the writ of error coram nobis. Humphreys v. State, 129 Wash. 309, 224 P. 937 (1924).

¿ State v. Asbell, 62 Kan. 209, 61 P. 690 (1900); Mandell v. People, 76 Colo. 296, 231 P. 199 (1924).

12 Collins v. State, $66 \mathrm{Kan} .201,71$ P. 251 (1903).

" Hamlin v. State, 67 Kan. 724, 74 P. 242 (1903).

4 State ex rel. Davis v. Superior Court, 15 Wash. 339, 46 P. 399 (1896).

t5 People v. Donahoe, 223 Ill.App. 277 (1921).

10 That is a matter that should have been presented at the original trial. Beard v. State, 81 Ark. 515, 99 S.W. 837 (1907).

17 Bennett v. State, 106 Miss. 103, 63 So. 339 (1913).

4 People v. Donahoe, 223 Iil. App. 277 (1921).

4 Humphreys v. State, 129 Wash. 309, 224 P. 937 (1924).

${ }^{10}$ (a) Ernst v. State, 179 Wisc. 646, 192 N.W. 65 (1923).

w People v. Black, 89 Cal.App. 219, 264 P. 343 (1928).
} 
ural rules of appeals and petitions for new trials, and (2) granting of the writ is in the sound discretion of the court, in many jurisditcions, and reversal will be ordered only where clear abuse is shown.

\section{Writs of Error Coram Nobis in North Carolina.}

The General Assembly of the State of North Carolina has recently passed legislation substantially affecting the availability of the writ of error coram nobis in that State. For that reason, attention will next be directed to the judicial development of the writ in North Carolina and the effect of the new legislation.

"The common law writ of error coram nobis to challenge the validity of petitioner's conviction for matters extraneous to the record is available under our procedure." Such was the holding of the Supreme Court of North Carolina in $1949 .{ }^{51}$

As authority for the writ in North Carolina, reference was made to North Carolina General Statutes $\$ 4-1$ which adopts the common law as the law of the state, when not modified, and to the State Constitution, Art. IV, §8, which gives the State Supreme Court authority to exercise supervision over the inferior courts of the State. The writ can only be granted in the court where the judgment was rendered. However, since in North Carolina the authority for the writ stems from the supervisory power given the Supreme Court, it is necessary that an application be made to the Supreme Court for permission to apply for the writ to the Superior Court in which the case was tried. After permission is granted, should the trial court deny the petitioner's application for the writ, it should find the facts, and petitioner will be allowed to appeal to the Supreme Court for review of the decision. If the Superior Court grants the writ, the judgment should be vacated, the pleas stricken or permitted

\footnotetext{
5I In re Taylor, 230 N.C. 566, 53 S.E.2d 857 (1949); "The common law writ of error coram nobis has been recognized and used in this state in similar situations from early times and is in common use elsewhere." State v. Daniels, 231 N.C. 17, 56 S.E.2d 2 (1949).
} 
to be withdrawn, and the case restored to the docket for trial in accordance with law..$^{32}$

Some of the more frequently cited cases on point, in North Carolina, will next be considered to point out the extent of and the limitations on the availability of the writ. One of the first reported decisions in re coram nobis in North Carolina was Tyler v. Morris, ${ }^{53}$ decided in 1839. There Morris made a motion for the writ before the Superior Court on the grounds that Tyler was dead at the time the judgment was rendered and also for a supersedeas to the execution on the judgment. The Superior Court denied the motion when Tyler's attorney joined issue as to the death of Tyler. The Supreme Court, on appeal, pointed out that before the writ will be allowed there must be an affidavit of some error of fact, by which, if the fact be true, the opposing party's right of action shall fail; that granting the writ is within the discretion of the trial court; that the trial court in determining whether to grant the writ does not base its decision on the existence of the alleged fact as the existence of the fact is to be determined in the subsequent trial, by a jury; and that the writ is not a supersedeas in itself but execution cannot be sued out on the judgment after the writ is granted, without leave of the court.

In Lathom v. Hodges, ,53 (a), a certain party contested a will and on appeal to the Supreme Court, the defendant was surety on the appeal bond; judgment in favor of the will was upheld in the Supreme Court and judgment was granted against the defendant on the appeal bond, by the Superior Court, this judgment being affirmed on appeal to the Supreme Court. Then the defendant sought a writ of error coram nobis on the grounds that the contestant of the will had died before the original trial before the Superior Court.

t2 Ibid. For an excellent short summary of the writ of error coram nobis in North Garolina, see report of J. C. B. Ehringhaus, Jr., special appointee of the Supreme Court, reported in 229 N.C. 297, 49 S.E.2d 749 (1948).

c3 Tyler v. Morris, 20 N.C. 625 (1839).

(a) Latham v. Hodges, 35 N.C. 267 (1852). For two interesting cases in the development of the writ in N.C., see Lassiter v. Harper, 32 N.C. 392 (1849) and Williams v. Edwards, 34 N.C. 118 (1951). 
The writ was denied. The court pointed out that the writ was here sought from a judgment of the Supreme Court and that the writ only lies in a court where the record and the judgment are, and not to reverse the judgment of another court, especially not a higher one. In subsequent cases concerning the writ, the Supreme Court of North Carolina has held that the writ may be addressed to a county court as that too is a court of record in North Carolina; that all parties plaintiff or parties defendant need not join in the application as one member alone may petition therefor $;^{64}$ that the writ will be denied where sought as a relief from a judgment granted against the petitioners on appeal bond and the petitioners had been joined as party plaintiffs without authority, for the appropriate remedy in such cases in North Carolina is a motion in the case. ${ }^{.5}$

In the case of In re Taylor, ${ }^{56}$ one of the most recent in North Carolina, the defendant had been tried and convicted of a capital offense without counsel; an attorney for the defendant applied for writ of habeas corpus to the Superior Court which denied it. The defendant then applied for certiorari for review of the ruling as to the petition for writ of habeas corpus and the Supreme Court affirmed the lower court's denial, noting that habeas corpus will not lie where persons are committed or detained by virtue of the final order, judgment, or decree of a competent tribunal of civil or criminal jurisdiction, or by virtue of an execution issued thereon. ${ }^{57}$ The court pointed out that the proper remedy would have been an application to the Supreme Court for leave to petition the Superior Court for writ of error coram nobis. ${ }^{58}$

During the 1950-51 Session of the North Carolina General Assembly, a step was taken substantially affecting the availability of the writ in this State. Chapter 15, of the General

\footnotetext{
is Roughton v. Brown, 53 N.C. 393 (1861). See also, Moore v. Hinnant, 90 N.C. 163 (1884).

$\approx$ Massie v. Hainey, 165 N.C. 174 (1914). Case contains excellent discussion of the writ.

so In re Taylor, supra, note 51.

or N.C. Gen. STAT, 1943, §17-4. In re Schenck, 74 N.C. 607 (1876).

s Accord: State v. Danlels, supra, note 51.
} 
Statutes, was amended to provide a remedy for persons convicted and imprisoned in the state penitentiary, other prisons of the state, and county jails who assert that rights guaranteed to them by the Constitutions of the United States or the State of North Carolina, or both, have been denied or violated, in trials or proceedings in which they were convicted, as to which there has been no adjudication. The act provides that a convict asserting such claim should commence the proceeding under this article by filing with the Clerk of the Superior Court his petition, verified by affidavit. The proceeding is special in nature with the judge making findings of fact and law and either granting or denying the application for a new trial. If the judge holds in favor of the petition for a new trial, appropriate orders are entered for rearraignment and retrial. If he should deny the petition, review may be had by application for certiorari to the Supreme Court of North Carolina. The act further provides that no action shall be brought thereunder more than five years after rendition of the final judgment resulting from a conviction, or more than three years after the effective date of this statutory provision, whichever is later, unless the petitioner alleges facts showing that the delay was not due to laches or negligence on his part.

It is apparent that the statute was passed primarily to deal with situations of the type presented in the case of In re Taylor, supra where a constitutional right has been denied. Though the statute is quite comprehensive in nature, it would seem that it replaces the writ of coram nobis only in those instances where it is claimed that a constitutional right has been denied, leaving untouched the availability of the writ for relief in other instances before mentioned, both civil and criminal; e.g., where the defendant subsequently claims insanity at the time of the original trial; where judgment was rendered against a minor; where a defendant has entered a plea of guilty in ignorance of the meaning, etc. For that reason, the writ of error coram nobis may still play a substantial part in the field of relief from error in North Carolina. 